\title{
The epidemiology of ostertagiasis in cattle in Finland
}

\author{
H.E. OKSANEN and S. NIKANDER \\ Department of Medicine, College of Veterinary Medicine \\ SF-OOSso Helsinki ss, Finland
}

\begin{abstract}
It has been shown that Ostertagia ostertagi, the brown stomach -worm, may have its prevalence all over Finland where cattle husbandry exists. The infection was able to over-winter on the pasture. The infection rate caused by the overwintered infection reached its maximum early in the spring and declined then successively until the middle of the summer. Thereafter, the number of the infective larvae on pasture began to increase again.

The infection rate on pasture was markedly higher close to the droppings than further away from them. It was shown that the vertical distribution of larvae on grass depends on the environmental humidity, temperature and light.

The weight gain of all experimental animals, controls as well as those of treated with anthelmintics was modest. Consequently the effect of the anthelmintic treatment could not be estimated.

Pathological changes in the abomasal wall caused by Ostertagia ostertagi were common, but only in a few cases were they severe. Neither did the abomasal $\mathrm{pH}$-value or the serum pepsinogen content suggest a severe ostertagiasis.
\end{abstract}

\section{Introduction}

The parasitic diseases in domestic animals belong to the most important diseases. The parasites inflict great economical losses on the whole animal husbandry, especially in warm climates and when the animals are undernourished or they are suffering from other diseases. Even in temperate zones, particularly under certain conditions, the parasites can bring about loss. It is well known in Finland that parasitic diseases may markedly influence the health of many farm animals, such as the horse, sheep, poultry, etc. Parasitic invasion frequently ends with death, particularly in the young animal.

Cattle kept in an unsatisfactory environment with low levels of hygiene are susceptible to different ectoparasitic invasions. However, their effect on the general health of the animals is seldom marked. The protozoal infection, piroplasmosis with haemoglobinuria and the trematodal liver fluke invasion, fascioliasis, were previously rather common in certain parts of Finland among cattle grazed on natural pastures. In southern and central Finland the nematodal lungworm infection, dictyocaulosis, called also husk, results occasionally in remarkable losses. The gastrointestinal nematode-invasion is not uncommon, but a systematic study on their prevalence in Finland has not been carried out. 
The gastrointestinal nematodes of cattle can be divided into the abomasal and intestinal parasites according to the localization of the adult parasites in the host animal. The three main genera of abomasal parasites are Haemonchus, Ostertagia and Trichostrongylus. Ostertagia is undoubtedly the most pathogenic and economically important gastrointestinal parasite of cattle in temperate areas (ARMOUR 1970). The parasite itself and the resultant disease, ostertagiasis, has been intensively studied in many countries; Great Britain, New Zealand, Germany, Holland, etc. (ARMOUR 1970, BRUNSDON 1972, ECKERT and BÜRGER 1979, KLOOSTERMAN et al. 1974). The Scandinavian countries too have studied the prevalence of ostertagiasis, its prevention and treatment. In 1975 it was proposed that cooperation between the different Scandinavian countries should be realized for the elucidation of problems concerning ostertagiasis. For this purpose a team, in which all the Scandinavian countries were represented, was established and the plan presented by the team was accepted by the Nordic Contact Organ for Agricultural Research, Nordisk kontaktorgan for Jordbruksforskning, NKJ, as project No. 36. The prime aim of the project was to coordinate the methodological and epidemiological investigations in the different Nordic countries in order to achieve practical methods for the countering of ostertagiasis. The project was started at the beginning of 1976 under the leadership of Dr. med. vet. Peter Nansen from the Royal Veterinary and Agricultural University, Copenhagen.

The economical and personal resources for veterinary parasitical research are extremely restricted in Finland. It should therefore be seen as an especially opportune possibility that we could participate in a joint undertaking with other Nordic countries. The restricted resources and the lack of suitable experimental herds limited investigations in Finland remarkably. However, many of the results obtained in the other Scandinavian countries during the period of study may be applicable in Finland.

\section{Material and methods}

The study of the occurrence and distribution of Ostertagia ostertagi was carried out on 33 grass samples taken from different geographical and climatological areas in Finland as shown in Fig. 1. The samples were collected in the spring just before the grazing season 1975-1978 from such pastures where cattle had been grazed the year before.

Annual and seasonal variation in the infective larvae (L3) population of Ostertagia were studied in 1976-1978 on two pastures of which one belonged to Westerkulla in the province of Uusimaa and the other to Hakoinen in the province of Häme both in southern Finland (Fig. 1). The grass samples, about 1/4 kg each, were taken before the grazing period, on some of the first pasture days, on the 20th, 35 th and the 50th day on the pasture and later on in the autumn after the end of the grazing period. The samples were taken close to the soil randomly from at least thirty different spots from both studied pastures.

The horizontal occurrence, that is to say the distribution of the infective larvae in the pasture field, was studied at the farms Westerkulla and Hakoinen in the year 1976. Grass samples were collected either close $(<20 \mathrm{~cm})$ to the droppings or 

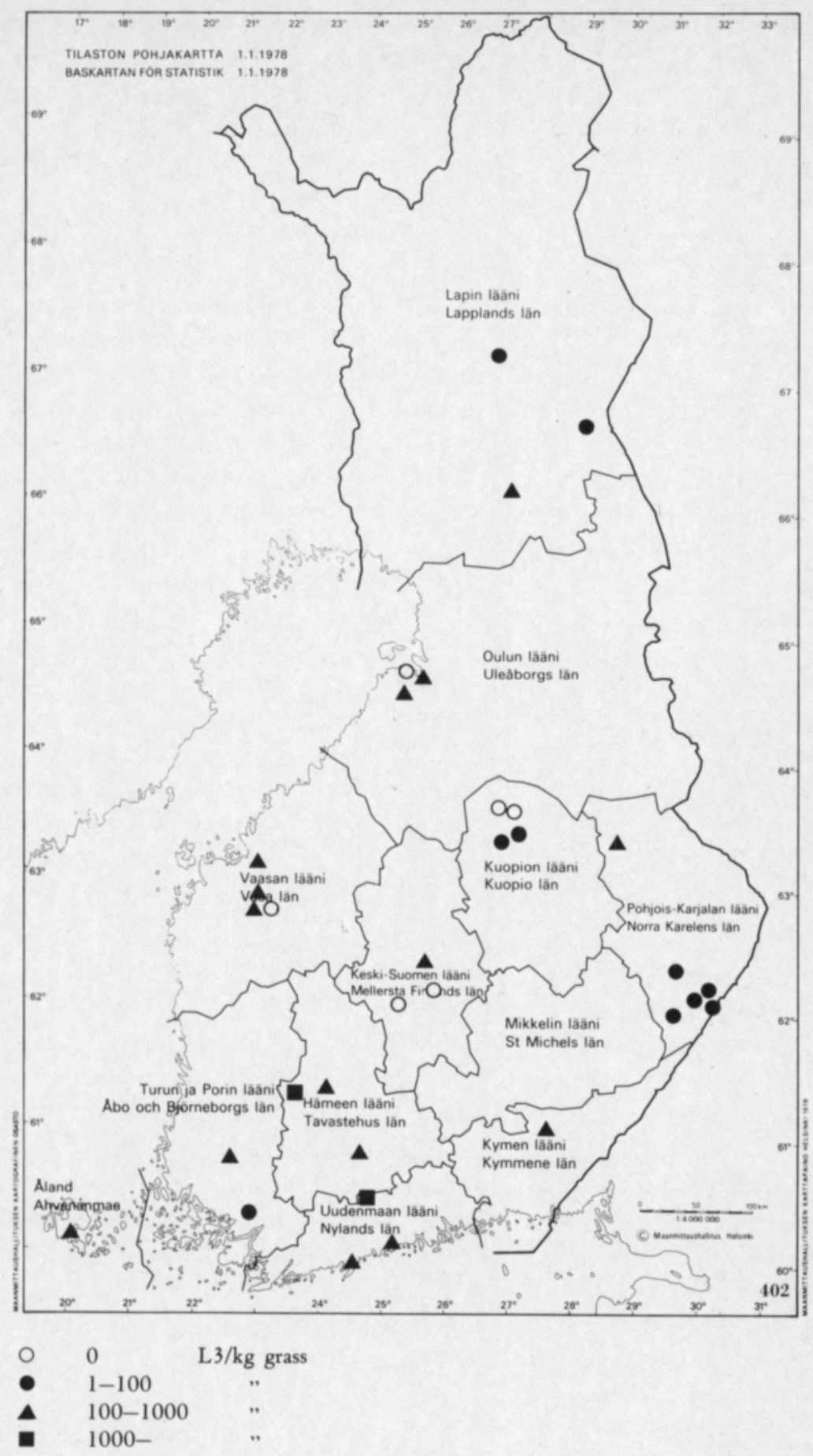

Fig. 1. Occurrence of Ostertagia larvae on the spring pasture vegetation. 
farther $(>20 \mathrm{~cm})$ from them. The samples were collected in the same way as described for the annual and seasonal variations.

In order to check the vertical distribution of the infective larvae in the vegetation during a twenty-four hours period, samples were collected at 6 hours intervals at Westerkulla on the 21-22 of May 1977. The grass samples, cut close to the soil, were halved and divided into a lower and upper group.

All grass samples collected for different purposes were put in plastic bags carried or sent by air to the College of Veterinary Medicine at Helsinki where they were stored in a refrigerator at $+4^{\circ} \mathrm{C}$. Within 3 days after the arrival of the samples they were weighed and put in gauze bags. These were kept overnight in buckets filled with tap water $\left(+30^{\circ} \mathrm{C}\right)$ in order to allow the larvae to emerge from the gauze bag into the water and sedimentate. The larvae were collected, identified by microscope as Ostertagia larvae (PACENOVSKY 1972). Larvae in $1 \mathrm{ml}$ of $10 \mathrm{ml}$ of the total amount of sediment were counted and their number was expressed ( $\mathrm{L} 3 / \mathrm{kg}$ grass).

The studies with experimental animals were carried out at the farms Westerkulla and Hakoinen, used also for herbage studies as described above. The experimental animals consisted of female calves and heifers of Ayrshire breed.

The animals were weighed before the pasture season and divided into two similar sized groups. The animals in one group were treated with levamisole chloride (RipercolR) $5 \mathrm{ml} \mathrm{i.m./100} \mathrm{kg} \mathrm{body} \mathrm{weight} \mathrm{on} \mathrm{the} 20$ th day on pasture. The other group consisted of untreated, control animals. In addition to the day of treatment the animals were also weighed on the 35 th, 50 th day on pasture and some of them were weighed again later, as shown in Figs. 5, 6 and 7. At the farm Hakoinen the experiment was carried out only during the summer of 1976. The animals were kept on a cultivated pasture, about one hectar in size.

At Westerkulla the trials were carried out in the years 1976-1978. The animals were grazed on an area of about 20 hectares. This consisted mostly of forest and natural pasture and only $2-3$ hectares were of cultivated pasture. During the first year there were 22 animals and in the second year there were 20 animals in the trials. Of the 20 animals (1977) one heifer intended for the treated group died before the 20th day on pasture. And one animal also belonging to the treated group was slaughtered before the 35 th day on pasture because of its aggressivness. The third year (1978) only 10 animals were available and the experiment was stopped unexpectedly because the animals could not be kept inside the fenced area.

Individual faecal samples were taken in connection with each weighing. The consistency of them was noted. The samples were stored in a refrigerator at $+4^{\circ} \mathrm{C}$ and examined during 1-4 days. A modified McMaster technique was used to determine the amount of nematode eggs per $\mathrm{g}$ faeces $(\mathrm{epg})$. Faeces $(5 \mathrm{~g})$ was mixed with $70 \mathrm{ml}$ saturated $\mathrm{MgSO}_{4}$-solution and epg was determined in two McMaster chambers (RAYNAUD 1969).

In the year 1977 a total of 100 blood samples were taken for the determination of serum pepsinogen content from all the experimental animals in connection with their weighings. The samples were allowed to coagulate overnight at $+4^{\circ} \mathrm{C}$ and then centrifugated. The serum was separated and stored at $-20^{\circ} \mathrm{C}$ until May 1978. These samples were sent deepfrozen to the Royal Veterinary and Agricultural University, Copenhagen, where the pepsinogen level was measured under the direction of Dr. med. vet. P. Nansen. 
Post mortem material was collected at two abattoirs; Lihakunta slaughterhouse in Rovaniemi and the Town slaughterhouse in Helsinki. At the Lihakunta slaughterhouse the abomasal mucosa from 40 young cattle was examined in September 1978. Immediately after the slaughter the abomasum was opened and it was noted whether there existed parasitic nodules in them. No classification of the infection rate was carried out. At the slaughterhouse in Helsinki 104 blood samples from young cattle were collected between June 1977 and May 1978 in connection with the blood-letting. The blood samples were handled, stored and analyzed for the serum pepsinogen content as described above. Of all the 104 animals presented above, the abomasum was tied up and cut off and brought to the College of Veterinary Medicine for closer examination. The content of the abomasum was collected in plastic vessels and the $\mathrm{pH}$ value was measured with a $\mathrm{pH}$ gauge within two hours after slaughter. The mucosa of the abomasum was washed with water and the number of nodules caused by the brown stomach -worms in each stomach were classified as follows: $-=$ no nodules, $+=a$ few nodules, $++=$ a moderate number of nodules and $+++=$ more than a moderate number.

\section{Results}

Of the 33 grass samples from different localities in our country only 6 samples did not contain any infective larvae of Ostertagia spp. 10 samples contained 1-100, 15 samples 100-1000 and 2 more than 1000 infective larvae/kg grass (Fig. 1).

Annual variation in the number of the infective larvae in the spring was marked

Fig. 2. Number of Ostertagia larvae on the pasture at Westerkulla.

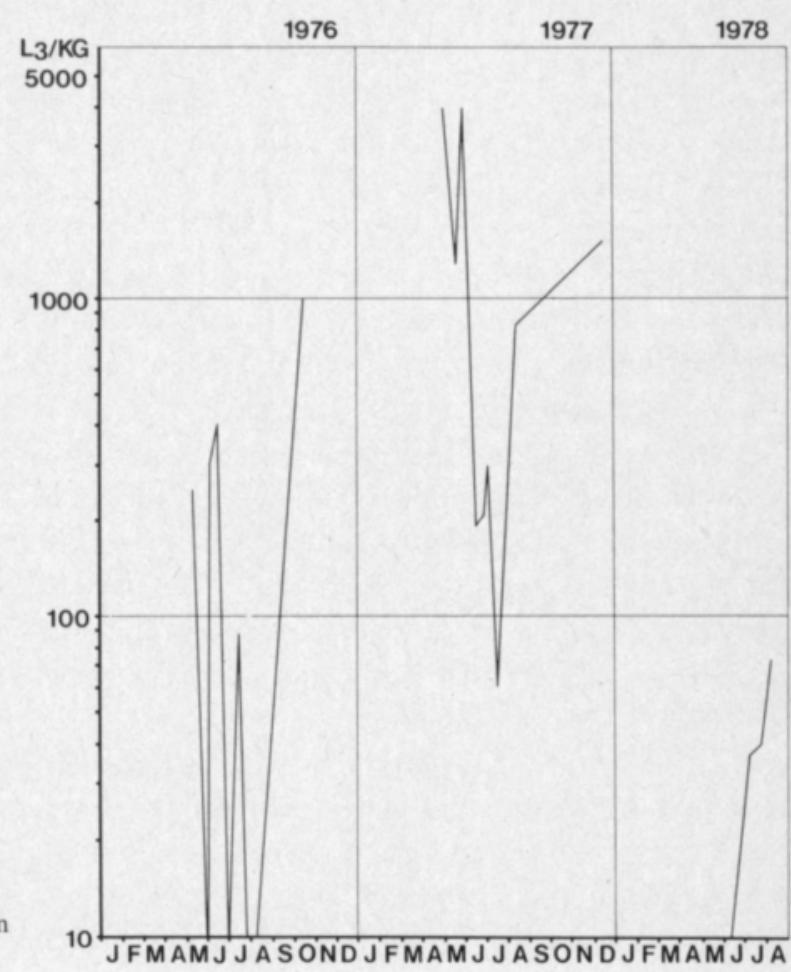




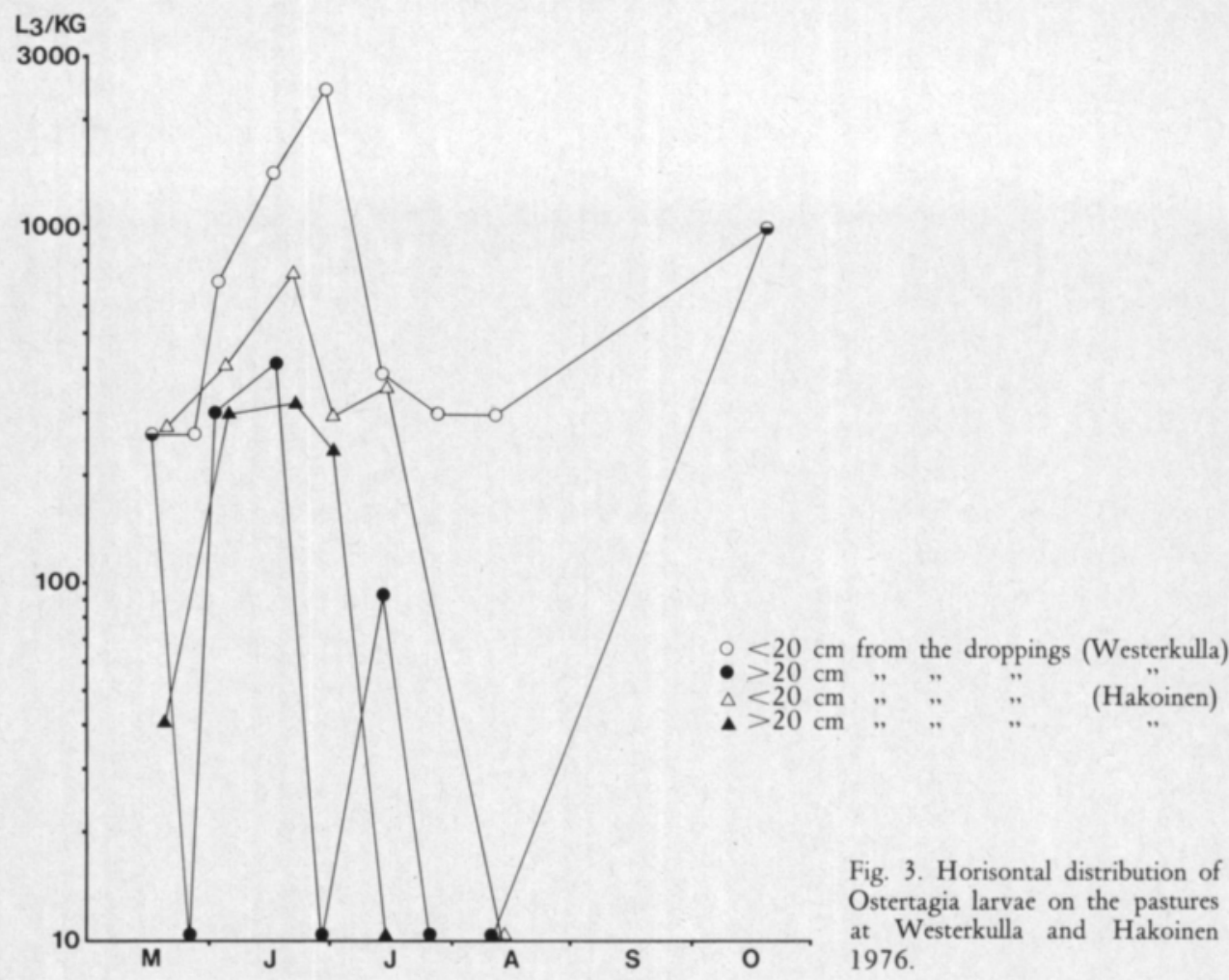

at Westerkulla. In May 1976 there were 250 , in the next year $3000 \mathrm{L3} / \mathrm{kg}$ grass and in May 1978 no infective larvae were found in the herbage (Fig. 2). The number of infective larvae reached a minimum in the middle of the summer and after this the number of the larvae began to increase again (Fig. 2).

A horizontal distribution with a higher number of infective larvae close to the droppings was observed (Fig. 3).

Day and night difference in vertical distribution of the infective larvae in the grass was noted. In the morning with a relatively higher humidity and lower temperature more larvae were found in the upper half of the grass. Later on during the day the opposite situation existed (Fig. 4).

The weight gains of the experimental animals at Hakoinen are presented in Fig. 5 and those at Westerkulla in Figs. 6 and 7. At Hakoinen a profuse diarrhoea was observed in 4 of the control calves and in 2 of the treated calves. All animals were put by the owner indoors on 30th July 1976 (50th day on pasture) and they were treated by the local veterinarian with Duoprim R (sulfadoxine + trimethoprim). As the main cause of the diarrhoea was verified by the State Veterinary Medical Institute an E. coli infection.

It can be seen from Fig. 5 that the epg numbers were rather low until the day of anthelmintic treatment. They increased after that markedly and reached their maximum (780) in the control group during the outbreak of the diarrhoea. After 2 weeks stay indoors the epg values were again clearly depressed. Consequently, possibly the diarhoea was at least partly influenced by an Ostertagia infection. 


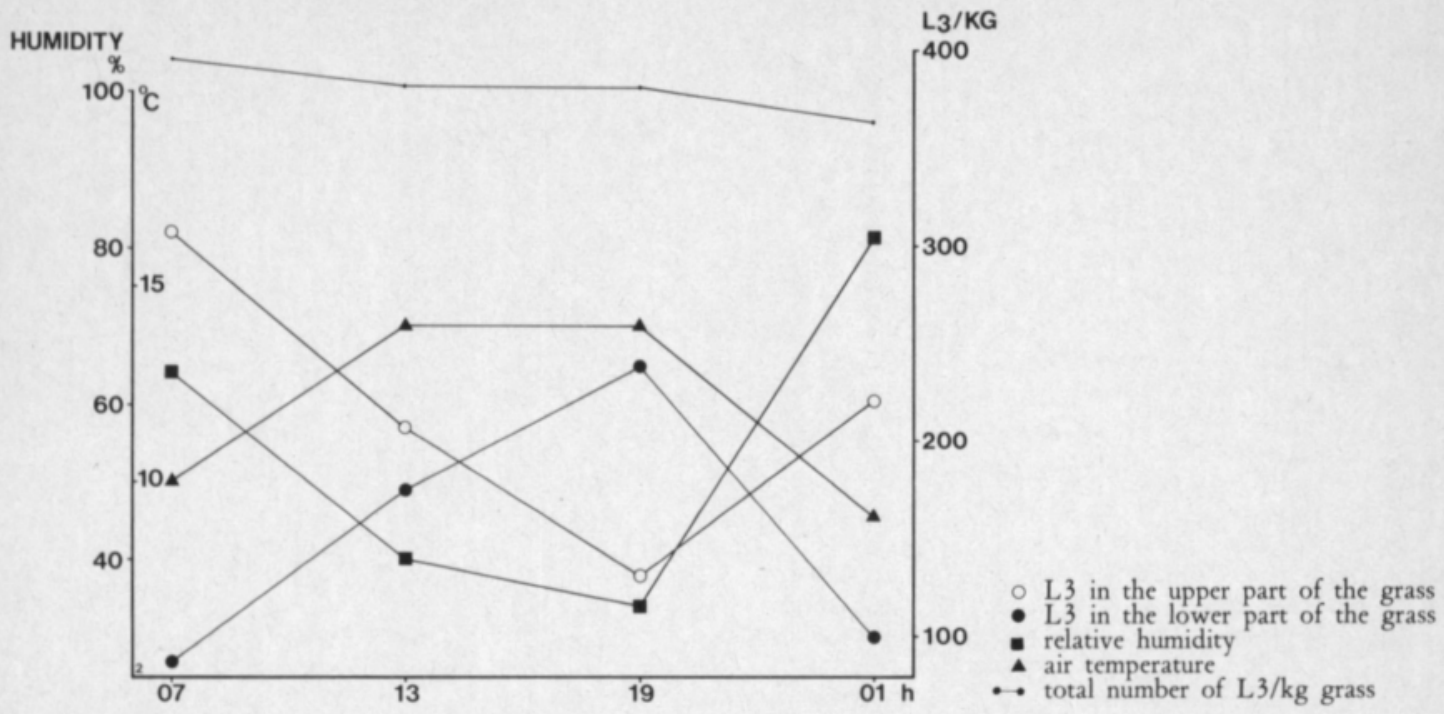

Fig. 4. Vertical distribution of Ostertagia larvae on the pasture during 24 hours at Westerkulla.

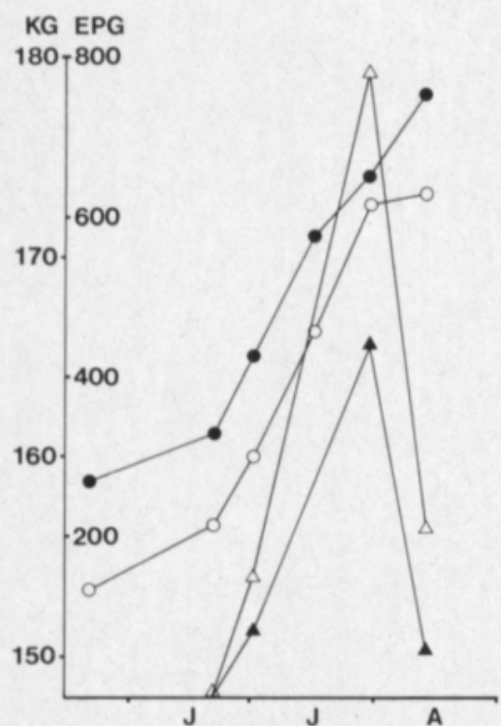

- A dewormed animals

$\Delta$ control

Fig. 5. Mean weight and epg of animals at Hakoinen 1976.

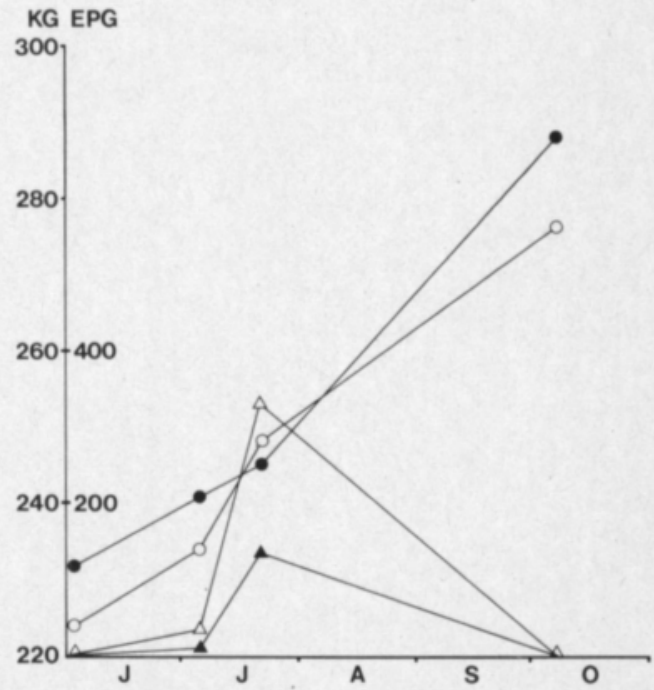

- A dewormed animals

$\Delta$ control

Fig. 6. Mean weight and epg of animals at Westerkulla 1976.

In the experimental animals at Westerkulla no serious diarrhoea was observed but the weight gain in 1976 was very modest and in 1977 it was practically nil for the de-wormed as well as for the control group. The variation of epg values at Westerkulla were, for both 1976 and 1977, very similar but did not reach such high peaks as were observed at Hakoinen. 


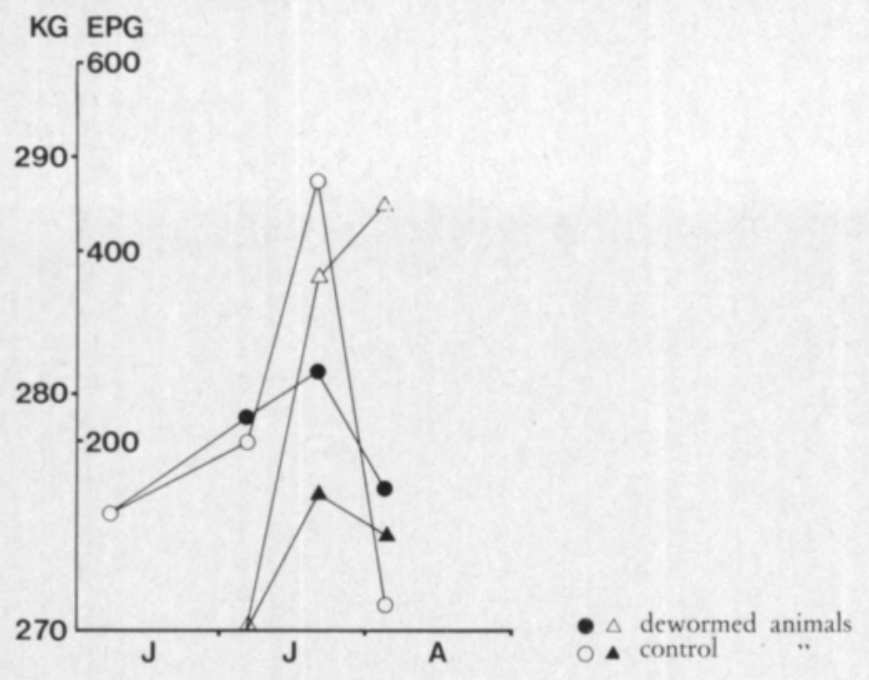

Fig. 7. Mean weight and epg of animals at Westerkulla 1977

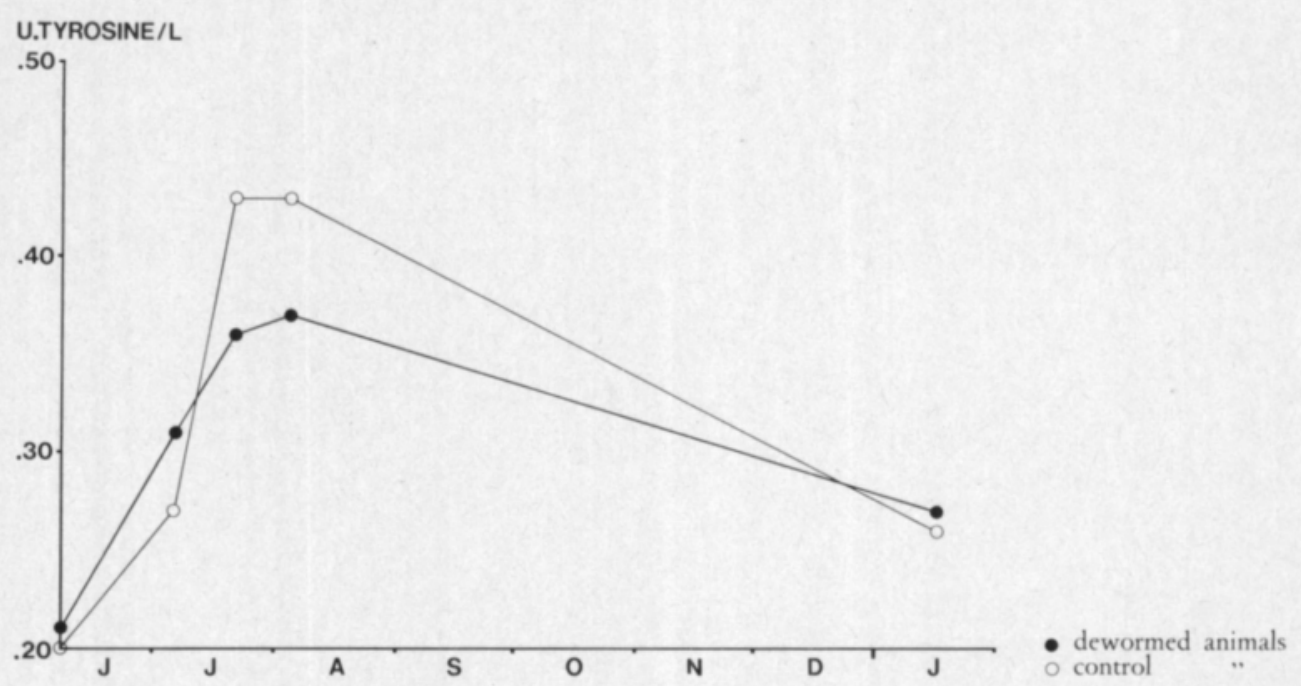

Fig. 8. Mean serum pepsinogen values of animals at Westerkulla 1977.

The variation curve for the mean serum pepsinogen content of the 8 treated and the 10 untreated animals at Westerkulla in 1977-1978 are presented in Fig. 8. The values for all animals should be considered as normal. The modest elevation in July-August correlated with the epg.

Pathological changes in the mucosa of the abemasum caused by the Ostertagia ostertagi invasion were rather common in the material collected at slaughterhouses. Of the 40 young animals examined at Rovaniemi slaughterhouse 39 were infected. In the slaughterhouse material from Helsinki abomasal nodules occurred in 86 animals out of 104 examined. Of the affected animals, 49 had only a few (+), 22 a moderate number $(++)$ and 15 more than a moderate number $(+++)$ of abomasal 
nodules. The mean $\mathrm{pH}$ value of the abomasal content of the noninfected animals was $5.0 \pm 0.9$ and for the infected animals $4.2 \pm 0.8$. The mean serum pepsinogen value was $0.54 \pm 0.17$. The highest value ( 1.3 units tyrosine/1) was observed in an animal which was slaughtered on 1 lth May 1978. The correlation between the $\mathrm{pH}$ values and serum pepsinogen content from corresponding animals was 0.05 (not significant). But for those animals with more than a moderate number $(+++)$ of parasitic nodules in the abomasal wall the correlation between the $\mathrm{pH}$ value of the abomasal content and the serum pepsinogen values was $0.62^{*}$.

\section{Discussion}

The brown stomach-worm of cattle Ostertagia ostertagi is a thin $0.5-1.0 \mathrm{~cm}$ long nematode. The larva L4, LS as well as the adult parasites live in the mucosa of the abomasal wall. According to Jennings et al. (1966) the female begins to produce eggs 18 days after the infection (p.i.) which follows the ingestion of L 3 larvae and takes place usually on the pasture. Consequently if cattle are infected at the very beginning of the pasture season one can expect the first Ostertagia eggs in their faeces about 3 weeks after the beginning of the grazing season. This means in southern Finland that the first parasite eggs should occur in the faeces of infected animals by the end of June. This was confirmed in the present investigation (Fig. 2). These eggs give rise to a new generation of larvae on the pasture. The time needed for the development of Ostertagia eggs to infective larvae (L3) is dependent on environmental humidity and temperature. In humid surroundings with from $15^{\circ} \mathrm{C}$ to $20^{\circ} \mathrm{C}$ it takes from 6 to 9 days (PANDEY 1972). In other words, the number of infective larvae on the pasture depends on the weather conditions.

In the middle of the summer the lowest number of infective larvae was observed in the pasture herbage at Westerkulla. This may indicate that the wintered larvae die and disapear from the herbage and that the new generation has not yet obtained a wider distribution. During the autumn the weather often is rainy and this favours the development of the larvae. This was shown in this study (Fig. 2). Later in the autumn the borderline for hatching temperature of the eggs is reached and the development of larvae ceases. A great number of the larvae do not die during the winter provided that a snowcover thick enough exists (NILSSON and SORELIUS 1973, THARALDSEN 1976). ANNILA (1969) has shown that under a $20 \mathrm{~cm}$ thick snowcover the temperature was $-2.5^{\circ} \mathrm{C}$ when the air temperature was $-22^{\circ} \mathrm{C}$. The thick snowcover and the rather scanty herbage $/ \mathrm{m}^{2}$ explains the high number of larvae in the spring pasture. In areas with spare snowcover which often exist in the coast region of Finland, a low number of overwintered infective larvae can be expected. In addition to the overwintering larvae Ostertagia eggs also survive the winter on the pasture and begin their development in the spring when the weather conditions become favorable (PERSSON 1974). This could explain the peak in the larvae number seen in June in the present study (Fig. 2). The number of the L3 larvae which causes the residual infection in the spring declines and reaches minimum in the middle of the summer as shown in Fig. 2. A similar pattern in the prevalence of L3 has been shown also in Scotland (MICHEL 1968), Canada (ANDERSON et al. 1969), Sweden (NILSSON and SORELIUS 1973), Norway 

1974).

However, the degree of infection of grazing animals depends on the stocking rate of the pasture as well as on the number of L 3 in the pasture areas. When a high stocking rate prevails the animals are forced to graze closer to the fecal pads and this inevitably leads to a higher worm uptake by the animals (NANSEN et al. 1977). In those animals infected in the spring or summer the ingested larvae cause a subclinical or clinical disease, summer ostertagiasis, also called ostertagiasis Type I.

The infective L3 are transformed in the rumen of the cattle to stage L4 (ECKERT et al. 1968). They are then rapidly transported aborally to the abomasum where they bury themselves into the mucosa of the abomasum. These larvae (L4) destroy the parietal cells which are responsible for the production of $\mathrm{HCl}$ and they form nodules characteristic for the invasion. After 16 days p.i. the larvae leave the nodules as pre-adult worms. As mentioned above the egg production starts 18 days p.i. and it continues for about 10 days (JENNINGS et al. 1966).

Because the $\mathrm{HCl}$ production is disturbed the abomasal $\mathrm{pH}$ value increases and the activation of pepsinogen to pepsin as well as the proteolytic activity of the abomasum decreases. This may be followed by a protein loosing enteropathy which is manifested as diarrhoea, reduced weight gain, hypoalbuminemia and raised serum pepsinogen level. Of these negative effects reduced weight gain is economically the most important (NILSSON and SORELIUS 1973).

The weight gains in the present study were modest even in those animals treated with anthelmintics at the start of the grazing period. It can be supposed that the modest weight gains of all the experimental animals at least partly were dependent on inadequate nutrition due to unfavorable weather conditions. Low weight gain might have been partly caused by re-infection because it was not possible to move the animals to clean pastures after the anthelmintic treatment. It has been shown that moving to clean fields alone can result in a better weight gain than anthelmintic treatment every third week during the grazing season without change of pasture (HENRIKSEN et al. 1976).

Serum pepsinogen level has a diagnostic value for damages in the abomasal mucosa and it has been used in the diagnosis of ostertagiasis. According to JORGENSENet al. (1976) and SCHULTZ (1977) the pepsinogen level varies in non infected calves from $0.3-0.7$ units of tyrosine/l. HANSEN (1979) reported that in manifested ostertagiasis the serum pepsinogen values exceed 2.0 units tyrosine/l. In the present study the pepsinogen values for all studied animals varied within normal limits.

In addition to the wintering of the eggs and infective larvae on the pasture as described above the larvae can survive in the host from one season to the next. This endogen alternative can be explained by the inhibited development of the larva in the abomasal mucosa.

ARMOUR et al. (1969) have shown that most of the infective larvae which were ingested at the end of the grazing period were inhibited, arrested in their development. The factors responsible for this suppression are not known. It has, however, been attributed to the presence and number of adult worms in the host animal and to different factors concerning the host animal, such as acquired resistance and the immunity against parasites which often depends on the age of the 
animal (SMITH 1974). But evidence is accumulating that the suppression is primarily a result of environmental influence on the infective larvae. It has been shown that storage of L3-larvae at $+4^{\circ} \mathrm{C}$ for 6 weeks inhibits the larval development until 40-60\% of the ingested larvae (ARMOUR and BRUCE 1974). According to SCHULTZ (1977) clinical signs can be expected in animals when there are $40000-100000$ infective larvae developing in the abomasal mucosa. The disease so caused is called winter-ostertagiasis or ostertagiasis Type II. The clinical signs of it are similar to those of summer ostertagiasis, diarrhoea, depression, loss of weight gain and in addition increased loss of plasma albumin into the abomasum (MULLIGAN et al. 1963) and anaemia (ARMOUR 1970). As the name indicates, the disease often occurs during the winter as has been shown in Great Britain among other countries. ARMOUR (1970) states that the inhibited period in the development of the larvae lasts 4-5 months and consequently the disease breaks out during the whole winter. Even in the Scandinavian countries, the disease is observed during the winter (OLSSON 1977, HANSEN 1979). However, at least in Sweden the culmination of the outbreaks is connected with the beginning of the pasture season (OLSSON et al. 1978). Since the symptoms of ostertagiasis Type II are unspecific and it often appears subclinically it is difficult to verify. The diagnosis is supported by the anamnetic knowledge of a preceeding pasture season of the animals. The serum pepsinogen content seems to be of diagnostic value first when the larvae start their development to adult parasites in the abomasal mucosa. Contrary to the adult parasites, the inhibited larvae seem to have a markedly lower influence on the serum pepsinogen values (OLSSON and HOLTENIUS 1980).

In the present study the only animal with an elevated serum pepsinogen value (1.3 units tyrosine/l) and with a high number of parasitic nodules $(+++)$ was slaughtered late in the spring (11th May, 1978). This might indicate that in Finland, as in Sweden, the ostertagiasis Type II may occur at the end of the inside feeding season or at the beginning of the pasture period.

\section{References}

ANDERSON, N., ARMOUR, J., JENNINGS, F. W., RITCHIE, J. S. D. \& URQUHART, G. M. 1969 The sequential development of naturally occuring ostertagiasis in calves. Res. Veter. Sci., 10:18-28.

ANNILA, E. 1969. Influence of temperature upon the development and voltinism of Ips typographus L. (Coleoptera, Scolytidae). Ann. Zool. Fenn. 6:161-207.

ARMOUR, J., JENNINGS, F. W. \& URQOUHART, G. M. 1969. Inhibition of Ostertagia ostertagi at the early fourth larval stage - II. The influence of environment on host or parasite. Res. Veter. Sci. $10: 238-244$.

- 1970. Bovine ostertagiasis: A review. Veter. Rec. 86:184-190.

- \& BRUCE, R. G. 1974. Inhibited development in Ostertagia ostertagi infections - a diapause phenomenon in a nematode. Parasitology 69:161-174.

BRUNSDON, R. V. 1972. Inhibited development of Ostertagia spp. and Cooperia spp. in naturally acquired infections in calves. N. Z. Veter. J. 20:183-189.

ECKERT, J., BÜRGER, H-J., KÖNIGSMANN, G., CHEVALIER, H-J. \& RAHMAN, M.S.A. 1968. Zur parasitären Gastroenteritis. I Mitteilung: Einmalige Infektion von Kälbern mit röntgenbestrahlten Ostertagia-Larven. Veter. Med. Nachr. Heft 2:91-115.

- \& BÜRGER, H-J. 1979. Die parasitäre Gastroenteritis des Rindes. Berl. Münch. tierärztl. Wschr. 92:449-457. 
HANSEN, J. W. 1979. Type II ostertagiose (Vinterostertagiose). Dansk Veter. Tidsskr. 62:233-239.

HENRIKSEN, Sv.Aa. 1974. Parasitologiske graesmarksundersogelser i Danmark. Proc. 12th Nord. Veter. Congr., Reykjavik, 83-84.

- 1975. Lobbe - tarmstrongylider hos kvaeg - II. En oversigt med saerligt henblik på Ostertagia ostertagi. Dansk-Veter. Tidsskr. 58:833-841.

- JØRGENSEN, R. J., NANSEN, P., SEJRSEN, Kr., BROLUND LARSEN, J. \& KLAUSEN, S. 1976. Ostertagiasis in calves. I. The effect of control measures of infection levels and body weight gains during the grazing season in Denmark. Veter. Parasit. 2:259-272.

JENNINGS, F. W., ARMOUR, J., LAWSON, D. D. \& ROBERTS, R. 1966. Experimental Ostertagia ostertagi infections in calves: studies with abomasal cannulas. Amer. J. Veter. Res. 27:1249-1257.

JØRGENSEN, R. J., HENRIKSEN, Sv.Aa., SEJRSEN, Kr. \& NANSEN, P. 1976. Serumpepsinogenanalysen og dens relation til bovin ostertagiose. Nord. Veter. Med. 28:210-216.

KLOOSTERMAN, A., BAAS, R. J. \& BRINK, v.d.R. 1974. Significance of overwintered pasture infection for Trichostrongylosis in calves. Tijdschr. Diergeneesk. 99:1053-1059.

MICHEL. J. F. 1968. The control of stomach-worm infection in young cattle. J. Brit. Grassl. Soc. 23:165173.

MUlligAN, W., DALTON, R. G. \& ANDERSON, N. 1963. Ostertagiasis in cattle. Veter. Rec. 75:1014.

NANSEN, P., JØRGENSEN, R. J., HANSEN, J. W. \& SEJRSEN, Kr. 1978. Some factors influencing the exposure of grazing cattle to Trichostrongyle infection. Veter. Scient. Commun. 2:193-205.

NILSSON, O. \& SORELIUS, L. 1973. Trichostrongyle infections of cattle in Sweden. Nord. Veter. Med. 25:65-78.

OLSSON, G. 1977. Vinterostertagios i Sverige - en slaktmaterialstudie. Sv. Veter. Tidn. 29:361-365.

- HOLTENIUS, P. \& HARALDSSON, I. 1978. Vinterostertagios - klinik och patologi. Sv. Veter. Tidn. 30:453-459.

- \& HOLTENIUS, P. 1980. Studies on the epidemiology of Ostertagia ostertagi in calves. Nord. Veter. Med. 32:28-37.

PACENOVSHY, J. \& KRUPICER, I. 1972. Differentialdiagnostik der Invasionslarven der gastrointestinalen Nematoden beim Rind. Folia Veter. XVI, 1-2:121-142.

PANDEY, V. S. 1972. Effect of temperature on development of the free-living stages of Ostertagia ostertagi. J. Parasit. 58:1037-1071.

PERSSON, L. 1974. Studies of the survival of eggs and infective larvae of Ostertagia ostertagi and Cooperia oncophora in herbage. Z. bl. Veter. Med. B. 21:787-798.

RAYNAUD, J-P. 1969. Techniques and Veterinary laboratory Parasitology. Booklet from Pfizer-Clin laboratories. Paris $44 \mathrm{p}$.

RICHTER, S. H. 1976. Parasites in sheep and cattle in Iceland. A preliminary report. Reykjavil 21 p.

SCHULTZ, A. 1977. Epidemiologiske studier over ostertagiose hos kalve. Undersogelse til belysning af den overvintrede infektions betydning. Ph. D. thesis, Copenhagen $157 \mathrm{p}$.

SMITH, H. J. 1974. Inhibited development of Ostertagia ostertagi, Cooperia oncophora, and Nematodirus helvetianus in parasitefree calves grazing fall pastures. Amer. J. Veter. Res. 35:935-938.

THARALDSEN, J. 1976. The epidemiology of Trichostrongylid infections in young cattle in Norway. Acta Veter. Scand. 17 Suppl 61:21 p.

Ms received April 24, 1981. 


\title{
Naudan ostertagiaasin epidemiologia Suomessa
}

\author{
H.E. Oksanen ja S. Nikander \\ Eläinlääketieteellinen korkeakoulu, Sisätautiopin laitos, Hämeentie 57, 00550 Helsinki 55
}

Ostertagia ostertagi, juoksutusmahan keskisuuri mato, kuuluu naudan tärkeimpiin loisiin. Porautumalla juoksutusmahan seinämän rauhasiin loiset vähentävät suolahapon tuotantoa. Tämän johdosta juoksutusmahan sisällön $\mathrm{pH}$ nousee ja pepsinogeenin muuttuminen pepsiiniksi vaikeutuu. Tästã taas seuraa ripuli sekä hypoalbuminemiaa. Koska tauti, ostertagiaasi, yleensã vaivaa nuoria eläimiä, niin ilmence ripulin vaikutus tavallisimmin hidastuneena kasvuna.

Ostertagiaasia erotetaan kahta tyyppiä, I ja II. Tyyppi I:ssä toukat viipyvät juoksutusmahan rauhasissa vain noin kolme viikkoa naudan saadessa tartunnan tavallisesti alkukesällä, siksi myös nimitys kesäostcrtagiaasi. Syyskesällä saatu infektio johtaa yleensä toukkakehityksen hidastumiseen, toukat jäävät juoksutusmahaan jopa useammaksi kuukaudeksi ja kehittyy talviostertagiaasi (Tyyppi II). Sukukypsãt parasiitit tuottavat isäntäeläinten ulosteiden mukana poistuvia munia, joista eri vaiheiden kautta kehittyy tartuntakypsiä (L3) toukkia. Tämä kehitys vaatii vähintāin viikon rïttävän lämpötilan ja kosteuden edistäessä kehitystä. Nauta saa tartunnan tavallisimmin laitumella syömällä laidunkasvustossa olevia toukkia.

Tarkempaa tietoa tämän parasiitin esiintymisestã ja merkityksestã maassamme ei ole ollut saatavissa. Vuonna 1975 heräsi ajatus yhteispohjoismaisesta tutkimuksesta tarkoituksena kehittää sellaisia menetelmiä, jotka loisivat perustan epidemiologiselle ostertagiaasin vastustamiselle. Suunnitelma hyväksyttiin NKJ:n tutkimusprojektiksi n:o 36. Se käynnistyi vuoden 1976 alussa ja täällä suoritetun tutkimuksen rahoitti Suomen Akatemian maatalous-metsätieteellinen toimikunta. Myönnetty määräraha rajoitti osaltaan tutkimussuunnitelmia. Suurin puute oli kuitenkin sellaisista riittävän suurista valtion tai yhteisöjen omistamista karjoista, joissa nuoria nautoja laidunnetaan.

Tutkimuksessa selvisi, että Ostertagia ostertagi esiintyy maassamme kaikkialla niillä alueilla, joissa karjataloutta harjoitetaan. Tartunta pystyy selviämään yli talven maassamme joitakin rannikkoseutuja lukuunottamatta yleisesti esiintyvån vahvan lumipeitteen suojassa. Talvehtineet loisten munat ja toukat jatkavat jo aikaisin kevãällä kehitystään saastuttaen kasvuston. Laidunten saastumisaste vähenee sittemmin selvästi kesän puoliväliin mennessä. Mikäli k.o. laitumella laidunnetaan eläimiä kasvaa sen saastumisaste uudelleen loppukesällä todennäköisimmin e!äinten erittämistä munista kehittyneiden toukkien aiheuttamana.

Kasvusto ulostepaakkujen lähellä oli huomattavasti voimakkaammin saastunutta kuin niistä kauempana kasvanut ruoho. Suuri eläintiheys pakottaessaan eläimet syömään lantapaakkujen lähiympäristötkin lisää selvästi tartuntavaaraa. Kasvuston horisontaaliseen saastumiseen, t.s. siihen, missä kasvien osissa toukkia runsaammin esiintyy eri vuorokaudenaikoina, vaikuttaa ympäristön kosteus, lämpötila ja valoisuus.

Teurastamomateriaalilla tehdyt tutkimukset osoittivat, että Ostertagia ostertagin aiheuttamat juoksutusmahan seinämämuutokset olivat varsin yleisiä, mutta vain hyvin harvoissa tapauksissa ne olivat vakavia. Eivät liioin juoksutusmahan $\mathrm{pH}$-arvot tai veriseerumin pepsinogeenipitoisuudet viitanneet vakavaan ostertagiaasiin

Koska niin koe- kuin kontrollieläimetkin eri kokeissa kasvoivat hyvin heikosti ja koska osa kokeista oli pakko keskeyttää, ei 20. laidunpäivänä annetun matolääkityksen vaikutusta eläinten terveyteen pystytty arvioimaan. Epidemiologisten tutkimusten perusteella voidaan kuitenkin esittää, että ostertagiaasin ehkäisyssä on erittäin tärkeätä katkaista infektioketju välttämällä nuorten nautojen laiduntamista pahasti saastuneilla laidunmailla, t.s. järjestämällä tarkoituksenmukainen laidunkierto. 